\title{
Demand Bubbles, Virtual Communities and Market Potential*
}

\author{
Flavio Gnecchi ${ }^{* *}$, Margherita Corniani ${ }^{* * *}$
}

\begin{abstract}
A virtual community is a precious information collation source allowing a company to identify conditions on which to base bubble information and indications regarding the time and manner on which the bubble should be triggered. Observations of virtual community dynamics, people entering and exiting, the length of their stay and so on, are fertile indicators for bubble potential in terms of dimension and timeframe.
\end{abstract}

Keywords: Demand Bubble; Global Competition; Virtual Communities; Segmentation; Intangible Assets

\section{Virtual Communities and Demand Aggregations}

The analysis of commercial opportunities offered by various markets, not only in relation to final but also to intermediate (or professional) demand, has revealed the efficacy of aggregate forms of development - even if focused, albeit not exclusively, on affirming a sense of belonging. Setting aside all technological considerations, one might say that the consumers of given goods or services, or even a retailer's or manufacturer's repeat customers, represent a community. That is to say, they constitute an aggregation based on shared needs and interests. This collective vision is not weakened by the fact that first the purchase and then the consumption (which coincide with regards to services) concern entirely individual actions.

It follows that communities of purchasers and consumers are akin to communities that, for instance, represent the social and administrative environment of a city or a district and, as such, are defined as local. Such communities may be characterized by shared entertainment (for instance a sports association), cultural interests or other things 1 .

\footnotetext{
* The Authors: F. Gnecchi $§ 1 ;$ M. Corniani $\S \S 2,3$

** Assistant Professor of Management, University of Milan-Bicocca, (flavio.gnecchi@unimib.it)

${ }^{* * *}$ Assistant Professor of Management, University of Milan-Bicocca, (margherita.corniani@ unimib.it)
} 
To this end, it is irrelevant whether the community is generated by commercial interests (e.g. retailers who exploit tools like loyalty cards) or generated by an individual person.

BMW fostered the development of what has become a well-known community of motorcyclists ${ }^{2}$. In addition to corporate communications and necessary practical information, it offers: events, products, news, history and even virtual product trials. It has become crucial to promoting events such as motorcycle rallies where participants can get to know one another in person, or by suggesting routes which then become leisure-time activities with the additional value of enhancing little known routes, townships and tourist/catering services in general.

In addition to shared interests, belonging to a 'commercial' community can also grow from the search for a sense of gratification, the need for protection, assurance, security and so on.

The appearance of new technologies, especially the most recent information technologies, has forced such issues to be reconsidered and provided the opportunity for the emergence of new forms of aggregation: that is, virtual communities. In addition to the search for the above 'senses', virtual communities hinge on shared common interests while the physical or spatial ${ }^{3}$ proximity bond becomes weaker. Papers and in-depth studies - written mostly by sociologists - and published on virtual communities have linked this concept exclusively to an ITC (Information Technology and Communications) framework, thereby excluding any other extension. We endorse this meaning of the adjective virtual used in the ITC sense (obviously when related to communities). This choice is borne out by analogy, through portals and/or specialized business sites that are commonly known as virtual marketplaces.

It follows that the subject of our interest becomes the online community (the same definition as provided for virtual communities). These new forms of aggregation are the focus for investigations carried out by companies interested in this novel type of retailing (the so-called e-tail), in an attempt to discover efficient ways of quelling competition notwithstanding the current over-supply ${ }^{4}$. Accordingly, a virtual community is a group of entities (individuals plus companies, organizations or institutions which take part through representatives) that share a common interest. In practice, the means which facilitate exchanges between community members and the community and between members and the companies which promote such communities, include emails, discussion forums (virtual meeting points), lists, notice boards and blogs.

Such communities, including online communities, represent a specific, welldefined target for company communications. Having duly selected the aims to be pursued, the consequent communications split with regards to customer aggregations, consumers or merely interested parties, is as follows 5 :

- aims targeting the development of business volumes, not exclusively in terms of quantity but also mix (commercial action);

- aims targeting the pursuit of in-house-organizational goals in terms of improved maintenance and operations regarding products-services offered; 
- institution-related aims, that is, aims intended to impact the environment in which the company-entity operates and with which it interacts.

Of the above, the first two concern this research paper more closely.

Both company action (communication) and the entity (the community) which the action addresses, that is to say the recipient, must be re-interpreted in terms of mutual contextual aims focused on increasing the relationship value linking the various players as well as increasing relationship duration. Company assets do not only include tangibles. Indeed, in no small measure they include active intangible elements such as culture, skills, projects, external relations and so on in addition to community consistency for the communities that interest the company. All of a sudden, communicating by ITC in support of a shared interest (virtual community) becomes a commercial opportunity with huge potential in so far that it is capable of intercepting requirements and needs (albeit not explicitly expressed) while developing a priority relationship with individuals.

A preliminary comment must be made with respect to online communities: access to the net is influenced by several variables. As a rule, access is easier for the younger, computer literate generations. In addition to the more immediate considerations, such as available information on consumers/members' age, location, disposable income and so forth, a company must obtain commercial information about their shopping habits, while also attempting to impact their shopping emotion.

As a result of the opportunities provided by ITC, the virtual community has become a formidable driver, generating epoch-making changes in corporate management strategies. The in-depth analysis of this trend might become a key factor in company success. With respect to more commercial aspects, innovative technological tools enable virtual communities to help companies review their segmentation approaches. Generally speaking, if technical peculiarities allow a community to be considered as a many-to-many, or even a many-to-one communications vehicle, then the community can also bring about a change in marketing dynamics in so far as it also represents an excellent one-to-one vehicle.

$\square$ In responding to a scheme launched by pharmacists, nearly all Japanese dwellings were equipped with a medicine cupboard in the nineteenth century. Pharmacists checked out supplies to monitor residual stocks of drugs, galenical preparations, herbal infusions, etc. on a weekly basis and replenished products when they ran low. In addition to regulating sales over time, this scheme allowed pharmacists to monitor consumption trends (and needs) thereby creating a priceless information asset ${ }^{6}$.

This example of one-to-one marketing is currently replicable by the opportunities made available by ITC. It has enabled individual segments to be isolated and, as a result, increased the potential for interaction open to individual community members. A number of related Internet-based tools now enable companies to monitor access and observe the navigation habits and procedures used by Internet users. The very use of ITC tools can become the means for selecting segmentation: 
from user-based segmentation (according to known methodologies, including geographical, personal data details, demographical, psychographic and so on) to usage-based segmentation ${ }^{7}$, which is marked by community Internet-user behaviour.

In addition to the widely used loyalty card, several commercial chains offer their customers and consumers the option to post comments, requests or appeals via public email (thereby creating a virtual meeting-place within their company) and obtain an answer that the whole community might read on a common electronic notice board.

$\square$ Coop Italia has consolidated its online presence. It has not limited
itself to managing the corporate website but promoted a virtual
community (called CoopCafé) which exists alongside the traditional
community. Its members receive a periodical publication and enjoy a
number of benefits and additional services. One only has to register to
become part of the community. In addition, a multi-ethnic forum can be
accessed that has, by default, generated an extended virtual community
for which no formal registration is required. Here surfers share
requests, comments and propositions (from within the same community)
with other members as well as the replies and further comments that the
company divulges.

In the existing economic panorama, new competitive factors are crucial. Such factors include time, and the ability to reach the target public by appropriately interpreting its needs and desires. In order to achieve this purpose, a community needs to be created that might develop into - as far as companies are concerned an effective test bed for new products evolved from competitive scenarios ${ }^{9}$. Therefore, the first goal for a company is to create a virtual community. This might be followed up by a number of commercial goals, even highly ambitious goals, in a time-based competition scenario.

A virtual community which helps do away with the concept of physical presence and space, represents the first objective to be realized and to which specific commercial goals can be later associated. Moreover, the community can be run as an instrument for increasing customer and consumer loyalty with regards to both the community name and brand management (or brands in the case of a brand portfolio). At the very least it can be operated to reduce 'disloyalty', an increasingly common behaviour nowadays given the excess of offerings.

As previously stated ${ }^{10}$, companies principally view virtual communities as instruments that are capable of redefining their own marketing policies. The appearance of Internet has meant that consumers are able to compare and assess products more effectively than in the past. Moreover, virtual communities provide a measure of the potential demand level, which continues to be the fundamental driver in corporate decision-making. Such communities enable demand to be assessed more accurately, and amongst other factors, is likely to be spread over a large and varied geographical area.

The sponsoring company must enjoy an excellent reputation in terms of trust and credibility within the community to cultivate not only customer loyalty but also 
especially the survival and development of the community itself. Such aspects have been chiefly fostered by direct relationships in the past (especially with longstanding companies). They must now involve the sublimation of key aspects including, in particular, the quality of the goods and services offered, price value, trustworthiness and so on. It must also be remembered that the development of ITC has, one way or another, enhanced the trust factor, as a value in itself. Indeed, there is no physical contact on the net, it is impossible to lay hands on an offering, purchase payments are carried out by remote means and delivery, which takes place at a later date, has to comply with the terms of the offering ${ }^{11}$.

In giving commercial aspects top priority, we need first of all to identify a community's degree of independence with regards to an offering. It must be remembered that a community might pre-date a corporate proposal or it might develop from input given by a company. In addition, the origin of communications must also be taken into account that is to say, whether a company or the members of a community started communications. Of specific and primary importance therefore, are actions that focus on influencing consumer requirements and habits. It is essential to measure the demand potential, a goal that requires companies to define new approaches.

In such cases, (online) market research is critical in so far that it might be able to gather the success potential of time-limited public offerings notwithstanding the instability of the market. It can do the same for the opposite case: stable aggregates (driven by their own motion or by corporate input) in shared interest groups, that is, online communities. Consequently, the commitment shown by companies must be reshaped and although the data collection cost trend is declining, the body of available news and data entails the development of new skills and increased costs for processing the information itself ${ }^{12}$.

Innovative technologies entail rethinking market research and, in particular, creating new forms of commitment focused on giving priority to strategic aspects. This is achieved by adopting an integrated approach that takes into account the critical nature of processing speed (and, subsequently, the ensuing analysis and adoption of strategies). That unavoidable necessity, that is, data mining speed, becomes critical when the offering hinges on market instability. However, before getting down to data mining, companies must define the search subjects in order to focus energy on discovering and subsequently processing data and news in line with company requirement criteria.

Moreover, companies must also take into account the significance that communications by word of mouth (obviously in an ITC context) assume by using a tool that allows people to congregate in a virtual meeting place. A community chats in a virtual meeting place. It is here that people 'listen' and 'talk' and the duly registered players relate to one another (even if and only to increase the wealth of information owned by a company). In this new virtual dimension, communications by word of mouth (one just has to think of opinion exchange in a discussion forum) significantly facilitates the redefinition of several fundamental market analysis tenets.

Any analysis of the potential and effect of online word of mouth communication must also take into account the peculiarities typifying the various members in a 
community or, at least, the various classes into which member behaviours can be categorised. Key players are not people who appear on a stable basis at a virtual meeting place in an online community. Rather, they are people who acquire a central role and become opinion leaders. As such, their observations and requests provide the company with key information. Nevertheless, it is not infrequent for the price - another key element in an offering - to be fixed on the basis of data collected from the online community in line with market development. In practice, customers are given a propositional role as they can help determine (or at least suggest) the monetary sacrifice that a company offering goods/services will subsequently ask customers to make.

Moreover, it must be remembered that the strength of the ties binding the components in a community varies. Alongside members who are loyal and keep in regular contact with others, there are members who are registered but only appear sporadically. In all cases, a company must transmit a fundamental message to ensure surfers realize that his/her transition from mere visitor to community member will benefit him/her. This means transmitting values, that is, conveying that the positive outcome of his/her choice will be translated into a greater degree of satisfaction.

\section{The Aggregation Potential in Demand Bubbles}

In markets where competition intensity is low and supply dynamics are stable, where purchase behaviour and consumption demand are substantially stable ${ }^{13}$, companies tend to develop demand analysis models that lead them to identify increasing complexities in demand itself. This is mostly due to a general lack of homogeneity in the composition of such markets. In order to handle said complexity, companies develop demand segmentation. That is to say, a process that allows them to split demand into sub-groups (segments) organized so as to group homogeneous units on the basis of predefined criteria (the basis of segmentation), which however, are absolutely non-homogeneous with regards to units belonging to other segments.

The splitting of demand is the first step in a company's response process to the market and the obvious consequence is the selection of target segments (targeting) and the identification of appropriate strategies to cover the segments by altering the profile of the company offering (positioning). This complex set of activities assumes that segmentation has been assessed correctly and will generate effective segments (that is, homogeneous, measurable, consistent and accessible). It assumes above all that market conditions allow all the processes to be developed, or better, that demand and supply are sufficiently stable so that segmentation, targeting and positioning will provide a company with the expected financial return.

The very foundations of market stability are eroded under more dynamic competition conditions (excess of supply), when supply exceeds demand. Indeed, not only is purchasing behaviour non-homogeneous with regards to demand but it is unpredictable in so far that it does not repeat. On the other hand, supply comprises a series of competing companies that, by driving product innovation and promotion cycles to the limit, increase market instability. This invalidates the bulk 
of demand analysis and segmentation that focuses on the historical organization of dynamics that, to all intents and purposes, has been superseded. Traditional segmentation, targeting and positioning become ineffective, in practice, in highly competitive markets typified by time-based competition. This occurs as markets are deprived of the necessary stable support. Companies are unable to keep up with the increasingly frenzied pace of events and are forced to accept market instability as a fact. They must attempt to conform and go onto the market with an appropriate offering profile that is capable of exploiting demand dynamics through the continuous aggregation of demand bubbles.

As previously stated ${ }^{14}$, demand bubbles identify temporary groups of purchasers that can be aggregated on the basis of specific shared characteristics regarding a given business offering. As such, they constitute a corporate response to unstable market conditions. Accordingly, just like segments, demand bubbles result from precise actions carried out by a company - although the conditions and dynamics that lead to the development of bubbles are radically different from the competitive conditions where segmentation is applied. Indeed, segments first of all require stable conditions. Bubbles, however, can only develop in totally unstable markets where demand is inured to extreme dynamism and is prompt at selecting the most appropriate offering over a very short timeframe - with utter disregard for brand loyalty. Moreover, segments are a theoretical disaggregation of demand in order to simplify any approach to the market and provide a company with the ideal potential reference customer profile for the development of an appropriate offering. The logic underpinning demand bubbles is absolutely the reverse as it is generated by time-dependent aggregation around a specific offering and represents a concrete group of non-ideal customers that scatters as soon as the purchase is completed.

Therefore, on the one hand, segments are theoretical groups, described only in ideal terms and which can be isolated and exploited only under stable conditions. On the other hand, bubbles are actual groups, described only in real terms and which can aggregate only under unstable conditions. In both cases, one of the most critical aspects in terms of business management is the quantification of typical size.

Segment consistency, that is, the certainty that the ideal profile encompasses a given number of potential buyers, is indeed an essential prerequisite for segmentation process efficacy. Likewise, the size of demand bubbles must be selected in advance in order to precisely organize the processes for the creation, development and exploitation of bubble potential. Indeed, both segments and bubbles must be sufficiently large (that is, to ensure a given sales volume) to allow a company to attain the desired results. This means that companies must know the level of resources that can be dedicated to a specific segment offering, or to activating a bubble and how to bring this about.

Segment size knowledge has its roots in the potential market development concept. In practice, companies must first understand the depth of the relevant market in order to know how many product units might be sold at a given place. Global demand, just like individual company demand, is a response function where the level depends on the degree to which a series of factors act, namely, demand determinants ${ }^{15}$. These determinants include ambient factors (for instance, cyclical economic trends, tax burden, and so on), and factors that can be controlled by the 
company, the so called marketing factors, which include the complex system of marketing actions carried out by competing companies. The effective potential market is a limit to which global demand tends when marketing pressure in the market is maximized, while the absolute potential market assumes that all potential customers make the maximum possible use of a given product.

Once the potential market concept has been recognized, a company must identify the size of the market segment. That is to say, the company must examine its historical competitive position and analyse its market share in relation to competitors so as to understand, segment by segment, what sales potential is reasonable for a specific brand offering. Once the ideal segment profile is known and once the market scope for that type of profile is known, the company may attribute a value in terms of consistency to each segment identified and then decide whether it is worthwhile or not to direct its offering to satisfy that demand.

This course of action assumes stability and defined market borders. Indeed, one must refer to a given market with clear borders (geographic, political, economic, and so on), in order to quantify demand. At least one must know exactly what falls 'within' this market and what falls 'outside' it. Stability relates to the concept that the market in question must manifest repeatable conditions over time, both with respect to ambient conditions and competition. In practice, companies must work things out so that their historical market share enables them to see future prospects when faced with moves by the competition. For instance, these environmental and competitive circumstances existed in specific Italian markets between the 70's and the 90's, and between the 60's and the 80's in other developed countries like the US. In reality, there 'must be time' or better, time must not be an active variable in the competitive system in order to quantify the potential market as described above.

The development of stable-market knowledge and an understanding of its critical dimensions (demand, distribution and competition) are ensured by the application of market research. It focuses on describing the state of several variables and through market research tries to identify the causes of the observed phenomena ${ }^{16}$. Such research is capable of offering accurate information about the certainty of a given phenomena over time. All research carried out in stable markets is based on exhaustive knowledge of the phenomena. Indeed, some research work derives from the data collected for census processing, that is to say, from surveys focused on examining all population units. When census taking becomes too costly or difficult to implement, sampling is adopted, that is to say, a calculated population sub-group selection is analysed instead of the entire population. However, the selection includes features that make it representative of the entire population. Census taking and sampling, albeit different in manner and cost, attempt to acquire exhaustive knowledge of today's reality. The former achieves this aim by analysing all units, the latter by analysing only given members selected on the basis of specific criteria so that it is reasonable to imagine that all units have been analysed. In practice, given that a universe's boundaries and limits are known, such analyses attempt to explain in an exhaustive manner the causes of phenomena therein (albeit not for individuals as the analysis is carried out at an aggregation level).

The aforementioned assumptions no longer hold true in markets typified by an excess of supply, that is to say, by strong competition as in most markets in 
developed countries. Market boundaries are not always clear. In fact, geographical and political borders do not always help to chart economic phenomena. National and supranational judicial powers (for instance, the European Union) have attempted to bring discipline belatedly and often in vain to bear on phenomena that elude localization. The logic by which all business activities must be characterized by a place of reference in turn allows for the definition of a clear system of responsibility. The Internet certainly provides a case in point: it is impossible to know the exact origin of a piece of information, a contact or a contractor. This in itself would not be significant if one did not consider that the very localization of the economic activities that make use of the Internet has replaced the former local/national framework, and has developed in line with what is currently called a global approach. With regards to economic activities in general, this approach will allow a business to localize over time to sites that have a positive impact on costs ${ }^{17}$.

Time becomes an active variable compared to competition dynamics in markets with over-supply. In practice, the pace of corporate actions and reactions is such that stability is seriously compromised. Accordingly, businesses cannot but acknowledge the endemic state of market instability. In such markets, there is not enough time to carry out analyses first and then perform the ensuing actions - as is the case in stable markets. Companies must act. It is up to management to decide when and how to perform the analyses that will focus an action, in other words, it relies on management's ability to organize business activities. However, it goes without saying that it is impossible to act without the support of guidelines provided by analysis. It follows that analysis and action must be carried out on the basis of new time-organization agendas (in comparison to stable markets). From a timing point of view, analysis is carried out at the same time as action, or at least, it is difficult to separate the two. Management analyses and chooses to act as it moves ahead. From an organizational standpoint, 'time wasting', indecision and delay factors must be reduced to a bare minimum in order to allow two processes, which were traditionally separate, to be carried out at the same time. The resulting flat organizations, known as lean organizations, not only have done away with entire organizational levels but have also radically altered operations at the remaining levels. People who act must also be able to perform the analyses that direct their actions. They follow a course mapped out by the people directing the business, and divulged in-house by way of a shared corporate culture that develops over time. That changing culture thereby reviews and re-shapes the course of the entire organization.

The manner by which companies devise and consolidate their responses to market instability does not only involve business organization, but the entire system underpinning the development of relations with the market. They create and manage demand bubbles. To this purpose, companies require a wealth of information - just as for the splitting of demand into segments and the management of business activities dedicated to each segment. In the case of demand bubbles, the information that allows companies to identify how and when to activate a bubble must be available, as the time factor is a key variable. The time and manner by which bubbles are created are tightly connected and must be defined accurately before a bubble gets active - on pain of forfeiting the entire process. The 'manner' in which a demand bubble is initiated concerns the type of offering made to the 
market, the quantities one estimates one can sell and the place or places where one intends to trigger the bubble.

'Time' means assessing when the time is right to make the offering (time value), defining the duration of the bubble (time duration) and controlling all related activities (from the collection and handling of information to the development of the overall logistics chain, including product supplies, manufacture and distribution) in the shortest possible timeframe (time compression) to avoid a reaction from the most agile competitors.

Hence demand bubble timing and way of being initiated and managed are closely linked as the choice of time for action and bubble duration impact the quantity of saleable products for a given type of offering. Likewise, the choice of a given offering also imposes specific demand bubble initiation timing and management. The quantification of demand bubble 'mass', that is to say, the so-called demand bubble potential, requires more critical processes than the realization of a demand bubble and in relation to the business results for the period. Businesses must develop appropriate information systems based on research methods and that are capable of providing information to help steer company management with precision in a very limited timeframe. The objective is to identify action timing, the appropriate offering and the size of the bubble to be triggered off.

Unlike in stable markets, such systems are not able to operate within an exhaustive logical framework for two reasons: first, because the relevant market borders are unknown, therefore the limit against which to measure information completeness cannot be identified and, second, because the time a similar approach would entail is not appropriate to the time-based competition of inter-competitive markets. Therefore, attempting to acquire exhaustive knowledge of the phenomena is not only unthinkable but also useless. Even if one were able to put together an exhaustive representation at time $t$, by time $t+1$, that is to say when a representation would be used for corporate decision-making, circumstances would be very different from those described at $t$. It follows that exhaustive approaches to information must be replaced by solutions appropriate to more dynamic competitive conditions, such as the selective approach to information that concentrates on indicative values. This approach, in particular, requires accurate meticulous descriptions of reality. Causal surveys focus on explaining the causes of phenomena so that they can be described in full and offer useful indications for preparing forecasts based on historical information reflecting events that have already happened.

A selective approach to information does however give preference to the selection of indicators that, appropriately interpreted, allow companies to identify future trends. A forecast is not, therefore, the result of an extrapolative process, rather it is the correct reading of today's existing indicators for tomorrow. Evidently, such an approach tends to have a significantly disruptive impact on corporate information systems. Therefore, companies are no longer interested in collecting huge quantities of data at high cost in order to ensure that the information obtained is representative and will lead to, at least in theory, impeccable forecasts collected into never ending reports that are difficult to read. On the contrary, the focus is now on the manner in which significant information is selected from the increasingly large amount of available information, at ever lower 
costs and showing key-phenomena trends (competition, developments in technology and legislation and so on).

Obviously, companies have already developed numerous tools, featuring a greater or lesser degree of complexity depending on the type of business and corporate culture. The most significant include:

- data mining techniques;

- competitive intelligence techniques;

- two-way communication tools;

- the creation of virtual communities.

In the majority of economic activities, the one most important single effect brought about by new information technologies is the habit of accumulating and filing masses of information about company processes. The mere fact that most corporate relations can be handled digitally (e.g. supplies, product marketing, personnel selection and training, prospecting and after-sales service) has lead to storing huge quantities of information on corporate IT systems using increasingly flexible storage methods. Information can be re-processed at any time using increasingly innovative techniques. This incomplete information, in terms of the market, can be appropriately processed to search for indicators that may in turn be the subject of further in-depth studies.

This search process can be carried out by applying data mining techniques to company databases, followed by the application of various algorithms on information and data that has been prepared appropriately. Complex iterative processes that compare and process huge masses of data can reveal links and trends that would otherwise not be apparent. Evidently, such IT techniques can be applied only in the case of vast quantities of data that have been stored in a flexible manner so that the preparation of algorithms is not too costly and yields results. However, these search techniques have definite limitations in terms of both cost and efficacy - as in the case of market and marketing research. Nevertheless, some businesses have succeeded in identifying several important areas of development in terms of company results:

$\square$ A well-known data mining technique application is widely used in international credit card circles. It looks for correlations in suspicious behaviour patterns in order to rapidly identify and block credit cards that appear to have been stolen so as to minimize losses for the industry. A database records all transactions made by each individual credit card introduced into the financial system. Database analysis allows for the identification of common behaviour patterns adopted by persons who have stolen cards. A monitoring system is structured to watch for any repetition in these patterns so that the authorities can act immediately. (http://it.sun.com/storiedisuccesso/diners.html).

Competitive intelligence makes use of a series of techniques borrowed from secret service espionage. The techniques are based on key-player business monitoring system developments. Although it differs from espionage in so far as all the actions carried out are legitimate, competitive intelligence is based on the 
selection of information sources to be monitored over time in order to process and feed information into the system. This entails systematizing information known to the general public; information on events/players that are considered critical for a business. Individual items of information are meaningless but when the items are linked up with other data, useful business decision-making pointers can be identified.

Another activity focuses on significant signals, especially with regards to players thought to be important sources of information for a business. It involves communications devised to handle two-way relations that develop between demand, supply and other key public entities in the market. To this end, public relations tools have become widely used over the past years. They rely on advanced logic and have been able to help companies acquire key information from the environment while providing the means for the same environment to be adequately shaped and informed about company activities and competitive responsibilities. Tools that have traditionally been less focused on managing competitive positioning, such as Customer Relationship Management (CRM), are being used increasingly alongside public relations. This tool drives a Direct Marketing application configured in competitive mode. It takes advantage of widely available ITC to enable users to initiate and control key relations with demand by applying mass tool logic and also by initiating personal contacts using named files.

Current CRM development is specifically based on the development of direct relations with demand (final or intermediate) using ITC tools that allow messages to be transmitted and recipient reactions to be handled. These reactions can be analysed individually or aggregated with other customers.

$\square$ Bticino is an Italian company owned by the Legrand Group. It is the leading manufacturer and seller of industrial and domestic electric switches in Italy. Over the past few yeas, it has made huge investments in support of a CRM project focused on profiling its customers (with specific reference to the so called 'prescribers', namely installers, sales points and architects). The goal is to manage the various relations with demand, both individually and as aggregates, as changes occur over time. In practice, Bticino has gathered the needed elements in order to select and focus offerings. It uses a database in which all the essential profiling elements for current or potential customers has been filed. Offers are targeted, only made at a given time and to given people using the aggregation logic of individual profiles that might be potentially interested.

The logic underpinning virtual communities is very much the same. As previously stated, these communities are groups of individuals brought together by a shared interest that companies can exploit in various ways. Hence, some communities may spring up spontaneously around an issue with businesses getting involved according to their own agenda. Companies might foster other communities, sometimes openly (through company websites for instance) or sometimes more surreptitiously by availing themselves of specialist professionals (such as online PR experts). In all cases, these communities provide a reference 
source for corporate information gathering. Indeed, these communities deal with issues that companies are interested in. Consequently they monitor communities and, wherever possible, try to guide discussions so as to obtain information that might be useful for company growth and for managing market interactions such as initiating a demand bubble. Observable community dynamics (discussion subjects, the number of contacts and level of participation, etc.) may provide companies with pointers that are often crucial when it comes to selecting one course of action over another.

As a rule, the first action that a company carries out on its own communities is profiling, that is, a procedure based on the collection of information about the people belonging to a community. Accordingly, companies manage to collect information about people who potentially share the same interests. Collection is on the basis of a self-selection process that usually only occurs after a community has developed dynamically and over time.

CDNow offers the potential to purchase various kinds of music online. When a surfer is interested in purchasing from the website, he/she registers and gets profiled by providing the most basic information about himself/herself (age, sex and other basic personal information for the completion of the transaction). Purchasers communicate his/her own IP to the website manager who immediately links it to the customer. At the same time, another crucial customer profiling element is given by the type of purchase, products selected or products merely perused. When a customer visits the website again, CDNow is able to speak directly to him/her by using his/her name and by suggesting offerings. These may be made on the basis of tastes indicated when he/she first visited the site or in relation to the CDNow customer community behaviour patterns that are best suited to his/her requirements. The customer may respond to this offer by helping the seller to better understand his/her tastes by, for instance, accepting an offer or by grading the offer so that CDNow will be able to make a future offer that is even more focused on the customer's needs. (www.cdnow.com).

Virtual communities, particularly ones promoted by companies, gather individuals who share at least one interest and about whom companies have acquired some basic information (especially in terms of traceability). Companies are hence able to become acquainted with tastes and reactions as action preferences are selected (obviously concerning interests underpinning the community). In practice, a community is a precious information collation source allowing a company to identify conditions on which to base bubble initiation and, more importantly, indications regarding the time and manner in which the bubble should be triggered. Communities produce information in terms of needs, complaints, criticisms and likes that can be examined further by guiding discussions or by using additional enquiry tools to focus on the more significant sources. Such information might offer indications as to the character of a potential bubble. 
Indeed, community information value is not limited to the existence of pointers that are able to direct choices towards the best offering. It also collects data on possible reactions to a company's proposal; that is to say, it identifies the magnitude of a potential bubble.

Observations of virtual community dynamics, people entering and exiting, the length of their stay and the interest shown allow companies to glean useful indicators about characteristic profile patterns for an offering tailored to suit a community at a given time compared to public interest in the specifics of the offering. Virtual communities are, therefore, the most fertile indicators for bubble potential in terms of scale and timeframe. A pre-condition is that the information from virtual communities is processed appropriately by IT systems and merged with results from other research focused on identifying trends and correlations such as competitive intelligence and data mining techniques - or other tools for generating two-way relations, such as current Direct Marketing applications. Then bubble potential can be assessed correctly (in terms of scale and timeframe) and qualified (with regards to the most appropriate type of offering) so that competitive financially attractive bubbles can be created and managed.

\section{Bibliography}

Aguilar Francis J., Scanning the Business Environment, Macmillan, New York, 1967.

Ansoff H. Igor, Implanting Strategic Information, Prentice Hall, New York, 1984.

Ansoff H. Igor, Managing Strategic Surprises by Response to Weak Signals, California Management Review, vol. 18, n. 2, 1975.

Babbar Sunil, Rai Arun, Competitive Intelligence for International Business, Long Range Planning, vol. 26, n. 3, 1993. http://dx.doi.org/10.1016/0024-6301(93)90012-5

Besson Bernard, Possin Jean-Claude, Du renseignement à l'intelligence économique, Ed. Dunod, Paris, 1996.

Bigus Joseph P., Data Mining with Neural Networks: Solving Business Problems from Application Development to Decision Support, McGraw-Hill, New York, 1996.

Bloch Alain, L'Intelligence économique, Economica, Paris, 1996.

Brondoni Silvio M., Comunicazione, risorse invisibili e strategia competitiva d'impresa, Sinergie, $\mathrm{n}$. 43-44, CUEIM, Verona, 1997.

Brondoni Silvio M., Global Markets and Market-Space Competition, Symphonya. Emerging Issues in Management (symphonya.unimib.it), n. 1, 2002.

http://dx.doi.org/10.4468/2002.1.03brondoni

Brondoni Silvio M., Brand Policy and Brand Equity, Symphonya. Emerging Issues in Management (symphonya.unimib.it), n. 1, 2000-2001. http://dx.doi.org/10.4468/2001.1.02brondoni

Brondoni Silvio M., Corniani Margherita, Di Gregorio Angelo, Sistema informativo aziendale $e$ relazioni tra imprese, Progetto Comunicazione Aziendale, Research Report n. 2/99, ISTEI University of Milan-Bicocca, January 2000.

Buttà Carmelo, La genesi dell'impresa. Fondamenti cognitivi e decisori, F. Angeli, Milan, 1995. 
Conca Valter, Le fonti di creazione del valore: la gestione strategica dell'informazione, Finanza, Marketing e Produzione, n. 1, 1994.

Conca Valter, Management intelligence e pianificazione, Economia \& Management, vol. 20, May 1991.

Corniani Margherita, Demand Bubble Management, Symphonya. Emerging Issues in Management (symphonya.unimib.it), n. 1, 2002. http://dx.doi.org/10.4468/2002.1.08corniani

Corniani Margherita, Sistema informativo aziendale e dinamiche competitive, Giappichelli, Turin, 2000.

Del Ciello Nicola, Dusi Susi, Saccardi Alberto, Metodi di data mining per il customer relationship management, Franco Angeli, Milan, 2000.

Dou Henry, Veille technologique et competitivité: intelligence économique au service du développement industriel, Ed. Dunod, Paris, 1995.

Drucker Peter, Can E-Commerce Deliver?, Business and Management, n. 122, 1999.

Easley Richard W., Virtual Communities ... The Power of Word-of-Mouth Transmission Via the Internet, The Journal of Internet Marketing, vol. 2, n. 1, March, 2002.

Fletcher Keith, Marketing Management and Information Technology, Prentice Hall, London, 1990.

Franch Mariangela, La comunicazione online. Aspetti metodologici e risultati di alcune sperimentazioni, CEDAM, Padua, 1999.

Gandolfi Valentino, Aree sistema: internazionalizzazione e reti telematiche, F. Angeli, Milan, 1988.

Garbelli Maria Emilia, Over-Supply and Manufacturing Localization, Symphonya. Emerging Issues in Management (symphonya.unimib.it), n. 1, 2002. http://dx.doi.org/10.4468/2002.1.10garbelli

Gnecchi Flavio, Comunità virtuali, comunità locali e comunicazione pubblica, Sinergie, CUEIM, Verona, n. 59, September-December 2002.

Golinelli Gaetano M., L'approccio sistemico al governo dell'impresa, vol. I, L’impresa sistema vitale, Cedam, Padua, 2000.

Kelley William T., Marketing Intelligence for Top Management, Journal of Marketing, vol. 29, October 1965.

http://dx.doi.org/10.2307/1249697

Kotler Philip, A Design for the Firm's Marketing Nerve Center, Business Horizons, vol. 9, n.3, 1966.

http://dx.doi.org/10.1016/0007-6813(66)90007-3

Kozienets Robert V., E-tribalized Marketing?: The Strategic Implications of Virtual Communities of Consumption, European Management Journal, n. 17, 1999.

http://dx.doi.org/10.1016/S0263-2373(99)00004-3

Lambin Jean-Jacques, La recherche marketing. Analyser, mesurer, prévoir, Ediscience International, Paris, 1990.

Lambin Jean-Jacques, Market-Driven Management, Macmillan Business, London, 2000.

Lambin Jean-Jacques, Marketing strategico e operativo, McGraw-Hill, Milan, 2000, p. 272.

Lambin Jean-Jacques, Brondoni Silvio M., Ouverture de 'Market-Driven Management', Symphonya. Emerging Issues in Management (symphonya.unimib.it), n. 2, 2000-2001.

http://dx.doi.org/10.4468/2001.2.010uverture

Lindstrom M., Click, Bricks and Brands, Etas, Milan, 2002.

Marchi Luciano, I sistemi informativi aziendali, II ed., Giuffré, Milan, 1993. 
Martinet Bruno, Marti Yves Michel, L’intelligence économique. Les yeux et les oreilles de l'entreprise, Les Editions d'Organisation, Paris, 1995.

Micelli Stefano, Imprese reti e comunità virtuali, Etas, Milan, 2000.

Montgomery David B., Urban Glen L., Marketing Decision-Information Systems: An Emerging View, Journal of Marketing Research, vol. II, May 1970.

http://dx.doi.org/10.2307/3150113

Prescott John E., Miller Stephen H. (eds.), Proven Strategies in Competitive Intelligence. Lessons from the Trenches, John Wiley and Sons, New York, 2001.

Pyle Dorian, Business Modeling and Data Mining, Morgan Kaufmann, Amsterdam, 2003.

Rouach Daniel, Veille technologique e intelligence économique, Que sais-je, Presse Universitaire de France, Paris, 1996.

Rozanski H.D., Bollman G, Lipman M., Seize the Occasion! The Seven-Segment System for Online Marketing, Strategy+Business, Booz-Allen \& Hamilton, New York, Issue 24, Third Quarter 2001.

Seurat Richard, Rougeaux Jacques, Intelligence Service et Marketing des Projects Industriels, Revue Française du Marketing, n. 127-128, 1990.

Sinkula James M., Market Information Processing and Organizational Learning, Journal of Marketing, vol. 58, January 1994, pp. 35-45.

http://dx.doi.org/10.2307/1252249

Talvinen Jary M., I sistemi informativi nel marketing, Come identificare le opportunità per nuove applicazioni, G. Cozzi, G. Ferrero (eds.), Le frontiere del marketing, Giappichelli, Turin, 1996, orig. ed., Information Systems in Marketing. Identifying Opportunities for New Applications, European Journal of Marketing, n. 1, 1995.

Wind Jerry, Mahajan Vijay, Digital Marketing, Symphonya. Emerging Issues in Management (symphonya.unimib.it), n. 1, 2002.

http://dx.doi.org/10.4468/2002.1.04wind.mahajan

\section{Notes}

${ }^{1}$ The case of the Italian Touring Club Italiano is emblematic: the Club counts over four hundred and fifty members who share an interest in tourism, conservation and heritage (see the website www.touringclub.it).

${ }^{2}$ To this end, visit the www.bmw-motorrad.it website which, although aimed at the Italian general public, has counterparts in most other major countries.

${ }^{3}$ C.f. J. Wind, V. Mahajan, who believe 'that a unique feature of digital communications is the potential to create virtual communities with customers that have shared interests', Digital Marketing, Symphonya. Emerging Issues in Management (symphonya.unimib.it), n. 1, 2002.

${ }^{4}$ C.f. J.J. Lambin, S.M. Brondoni, Ouverture de 'Market-Driven Management', Symphonya. Emerging Issues in Management (symphonya.unimib.it), n. 2, 2000-2001.

5 C.f. S.M. Brondoni, Comunicazione, risorse invisibili e strategia competitiva d'impresa, Sinergie, n. 43-44, 1997, pp. 10-11, CUEIM - Verona, who observes that 'with specific reference to the end purpose, corporate communications can be qualified traditionally as differentiating between pervasive and commercial communications which concern information flows tightly linked to the corporate mission, institutional communications that focus on creating a favourable response in the environment and use groups of 'opinion leaders/makers' as a mouthpiece. Such groups are not directly linked to business activities, however they influence business in a specific way (for instance, public organizations, financial brokers, shareholders, etc.), and organization communications that focus on reaching 'optimum' business conditions. 
${ }^{6}$ The news is reported by M. Lindstrom, Click, Bricks and Brands, Etas, Milan, 2002.

${ }^{7}$ C.f. H.D. Rozanski, G. Bollman and M. Lipman, Seize the Occasion! The Seven-Segment System for Online Marketing, Strategy + Business, Booz-Allen \& Hamilton, New York, Issue 24, Third Quarter 2001.

${ }^{8}$ There were approximately 4,995,000 Coop Italia members at the end of 2003, see www.coop.it.

${ }^{9}$ To this end, please refer to the opinion expressed by S.M. Brondoni, Global Markets and Market-Space Competition, Symphonya. Emerging Issues in Management (symphonya.unimib.it), $\mathrm{n}$. $1,2002$.

${ }^{10}$ Among others by S. Micelli, Imprese reti e comunità virtuali, Etas, Milano, 2000.

${ }^{11} \mathrm{P}$. Drucker, observing that cars are also available on the net, commented that 'in most businesses today delivery is considered as a support function, a routine to be taken care of by clerks. It is taken for granted unless something goes dramatically wrong. But under e-commerce, delivery will become the one area in which a business can truly distinguish itself. It will become the critical core competence. Can e-commerce deliver?, Business and Management, 2000.

${ }^{12}$ C.f. J. Wind, V. Mahajan, Digital Marketing, Symphonya. Emerging Issues in Management (symphonya.unimib.it), n. 1, 2002.

${ }^{13}$ Such conditions can be observed in the so-called markets dynamically balanced between supply and demand, in which the conditions for affirming the 'welfare state' are developed. C.f. S.M. Brondoni, 'Comunicazione, risorse invisibili e strategia competitiva d'impresa', S.M. Brondoni (ed.), La comunicazione d'impresa, Sinergie, n. 43-44, 1997.

${ }^{14}$ C.f. M. Corniani, Demand Bubble Management, Symphonya. Emerging Issues in Management (symphonya.unimib.it), n. 1, 2002.

${ }^{15}$ C.f. J.J. Lambin, Marketing strategico e operativo, McGraw-Hill, Milan, 2000, p. 272.

${ }^{16}$ C.f. J.J. Lambin, La recherche marketing. Analyser, mesurer, prévoir, Ediscience International, Paris, 1990.

${ }^{17}$ C.f. M.E. Garbelli, Over-Supply and Manufacturing Localization, Symphonya. Emerging Issues in Management (symphonya.unimib.it), n. 1, 2002. 